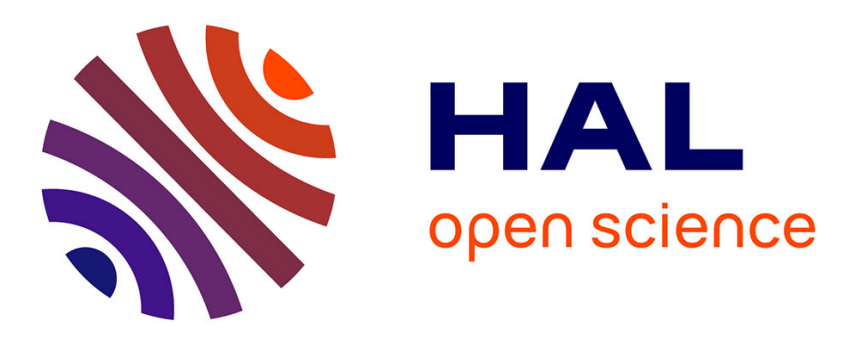

\title{
Rethinking False Spring Risk
}

\author{
C. J Chamberlain, B. I. Cook, Inaki Garcia de Cortazar Atauri, E. M. \\ Wolkovich
}

\section{To cite this version:}

C. J Chamberlain, B. I. Cook, Inaki Garcia de Cortazar Atauri, E. M. Wolkovich. Rethinking False Spring Risk. Global Change Biology, 2019, 10.1111/gcb.14642 . hal-02626157

\section{HAL Id: hal-02626157 \\ https://hal.inrae.fr/hal-02626157}

Submitted on 26 May 2020

HAL is a multi-disciplinary open access archive for the deposit and dissemination of scientific research documents, whether they are published or not. The documents may come from teaching and research institutions in France or abroad, or from public or private research centers
L'archive ouverte pluridisciplinaire HAL, est destinée au dépôt et à la diffusion de documents scientifiques de niveau recherche, publiés ou non, émanant des établissements d'enseignement et de recherche français ou étrangers, des laboratoires publics ou privés. 
MS. CATHERINE JEAN CHAMBERLAIN (Orcid ID : 0000-0001-5495-3219)

Article type : Opinion

\section{Rethinking False Spring Risk}

Authors:
C. J. Chamberlain ${ }^{1,2}$, B. I. Cook ${ }^{3}$, I. Garcia de Cortazar Atauri ${ }^{4}$ \& E. M. Wolkovich ${ }^{1,2,5}$

Author affiliations:

${ }^{1}$ Arnold Arboretum of Harvard University, 1300 Centre Street, Boston, Massachusetts, USA;

${ }^{2}$ Organismic \& Evolutionary Biology, Harvard University, 26 Oxford Street, Cambridge, Massachusetts, USA;

${ }^{3}$ NASA Goddard Institute for Space Studies, New York, New York, USA;

${ }^{4}$ French National Institute for Agricultural Research, INRA, US1116 AgroClim, F-84914 Avignon,

France

${ }^{5}$ Forest \& Conservation Sciences, Faculty of Forestry, University of British Columbia, 2424 Main Mall, Vancouver, BC V6T $1 Z 4$

This article has been accepted for publication and undergone full peer review but has not been through the copyediting, typesetting, pagination and proofreading process, which may lead to differences between this version and the Version of Record. Please cite this article as doi: $10.1111 / \mathrm{gcb} .14642$

This article is protected by copyright. All rights reserved. 
*Corresponding author: 248.953.0189; cchamberlain@g.harvard.edu

Keywords: false spring, phenology, freezing tolerance, climate change, forest communities

Paper type: Opinion

\section{Abstract}

Temperate plants are at risk of being exposed to late spring freezes. These freeze events-often called false springs-are one of the strongest factors determining temperate plants species range limits and can impose high ecological and economic damage. As climate change may alter the prevalence and severity of false springs, our ability to forecast such events has become more critical, and it has led to a growing body of research. Many false spring studies largely simplify the myriad complexities involved in assessing false spring risks and damage. While these studies have helped advance the field and may provide useful estimates at large scales, studies at the individual to community levels must integrate more complexity for accurate predictions of plant damage from late spring freezes. Here we review current metrics of false spring, and how, when and where plants are most at risk of freeze damage. We highlight how life stage, functional group, species differences in morphology and phenology, and regional climatic differences contribute to the damage potential of false springs. More studies aimed at understanding relationships among species tolerance and avoidance strategies, climatic regimes, and the environmental cues that underlie spring phenology would improve predictions at all biological levels. An integrated approach to assessing past and future spring freeze damage would provide novel insights into fundamental plant biology, and offer more robust predictions as climate change progresses, which is essential for mitigating the adverse ecological and economic effects of false springs.

This article is protected by copyright. All rights reserved. 


\section{Introduction}

Plants from temperate environments time their growth each spring to follow rising

temperatures alongside the increasing availability of light and soil resources. During this time, individuals that budburst before the last freeze date are at risk of leaf loss, damaged wood tissue, and slowed canopy development (Gu et al., 2008; Hufkens et al., 2012). These damaging late-spring freezes are also known as false springs, and are widely documented to result in adverse ecological and economic consequences (Ault et al., 2013; Knudson, 2012).

Climate change is expected to cause an increase in damage from false spring events due to earlier spring onset and potentially greater fluctuations in temperature in some regions (Inouye, 2008; Martin et al., 2010). In recent years multiple studies have documented false springs (Augspurger, 2009, 2013; Gu et al., 2008; Menzel et al., 2015) and some have linked these events to climate change (Allstadt et al., 2015; Ault et al., 2013; Muffler et al., 2016; Vitra et al., 2017; Xin, 2016). This interest in false springs has led to a growing body of research investigating the effects across ecosystems. Such work builds on decades of research across the fields of ecophysiology, climatology, ecosystem and alpine ecology examining how spring frosts have shaped the life history strategies of diverse species and determine the dynamics of many ecosystems, especially in temperate and boreal systems where frost is a common obstacle to plant growth. While this literature has highlighted the complexity of factors that underlie false springs, many current estimates of false spring risk and damage seek to simplify the process.

Current metrics for estimating false springs events often require only two pieces of information: an estimate for the start of biological 'spring' (i.e., budburst) and whether temperatures below a particular threshold occurred in the following week. Such estimates provide a basic understanding of potential false spring damage. However, they inherently assume consistency of damage across functional groups, species, life stages, and regional climates, ignoring that such factors can greatly impact plants' false spring risk. As a result, such indices may lead to inaccurate estimates and predictions, slowing our progress in understanding false spring events

This article is protected by copyright. All rights reserved. 
and how they may shift with climate change. To produce accurate predictions, researchers need improved methods that can properly evaluate the effects of false springs across diverse species and climate regimes.

In this paper we highlight the complexity of factors driving a plant's false spring risk and provide a road map for improved metrics. We show how freeze temperature thresholds (Lenz et al., 2013), location within a forest or canopy (Augspurger, 2013), interspecific variation in tolerance and avoidance strategies (Martin et al., 2010; Muffler et al., 2016), and regional effects (Muffler et al., 2016) unhinge simple metrics of false spring. We argue that while current simplified metrics have advanced the field and offer further advances at large scales, greater progress can come from new approaches. In particular, approaches that integrate the major factors shaping false spring risk would help accurately determine current false spring damage and improve predictions of spring freeze risk under a changing climate - while potentially providing novel insights to how plants respond to and are shaped by spring frost. We focus on temperate forests, where much recent and foundational research has been conducted, but our approaches can be extended to other ecosystems shaped by spring frost events.

\section{Defining false springs}

\section{When are plants vulnerable to frost damage?}

At the level of an individual plant, vulnerability to frost damage varies across tissues and seasonally with plant development. Different tissues are often more or less sensitive to low temperatures. Flower and fruit tissues are often easily damaged by freezing temperatures (Augspurger, 2009; CaraDonna \& Bain, 2016; Inouye, 2000; Lenz et al., 2013), while wood and bark tissues can survive lower temperatures through various methods (Strimbeck et al., 2015). Similar to wood and bark, leaf and bud tissues can often survive lower temperatures without damage (Charrier et al., 2011). However, for most tissues, tolerance of low temperatures varies seasonally with the environment through the development of cold hardiness (i.e. freezing

This article is protected by copyright. All rights reserved. 
tolerance), which allows plants to survive colder winter temperatures through various physiological mechanisms (e.g., deep supercooling, increased solute concentration, and an increase in dehydrins and other proteins, Sakai \& Larcher, 1987; Strimbeck et al., 2015).

Cold hardiness is an essential process for temperate plants to survive cold winters and hard freezes (Vitasse et al., 2014), especially in allowing bud tissue to overwinter without damage. Much cold hardiness research focuses on vegetative and floral buds, especially in the agricultural literature, where buds greatly determine crop success each season.

The actual temperatures that plants can tolerate vary strongly by species (Figure 1) and by a tissue's degree of cold hardiness. During the cold acclimation phase — which is generally triggered by shorter photoperiods (Howe et al., 2003; Charrier et al., 2011; Strimbeck et al., 2015; Welling et al., 1997) and, in some species, cold nights (Charrier et al., 2011; Heide et al., 2005) - cold hardiness increases rapidly as temperate plants begin to enter dormancy. At maximum cold hardiness, vegetative tissues can generally sustain temperatures from $-25^{\circ} \mathrm{C}$ to $40^{\circ} \mathrm{C}$ (Charrier et al., 2011; Körner, 2012; Vitasse et al., 2014) or sometimes even lower temperatures (to $-60^{\circ} \mathrm{C}$ in extreme cases, Körner, 2012). Freezing tolerance diminishes again during the cold deacclimation phase, when metabolism and development start to increase, and plant tissues become especially vulnerable.

Once buds begin to swell and deharden, freezing tolerance greatly declines and is lowest between budburst to leafout (i.e., -2 to $-4^{\circ} \mathrm{C}$ for most species), then generally increases slightly once the leaves fully mature (i.e., at this stage most species can sustain temperatures at least 1$4^{\circ} \mathrm{C}$ lower than they can between budburst to leafout, Sakai \& Larcher, 1987; Lenz et al., 2013). Thus, plants that have initiated budburst but have not fully leafed out are more likely to sustain damage from a false spring than individuals past the leafout phase (Lenz et al., 2016). This timing is also most critical when compared to the fall onset of cold hardiness: as plants

This article is protected by copyright. All rights reserved. 
generally senesce as they gain cold hardiness, tissue damage during the fall is far less common and less critical (Estiarte \& Peñuelas, 2015; Liu et al., 2018).

Temperate forest plants, therefore, experience elevated risk of frost damage during the spring due both to the stochastic timing of frosts and the rapid decrease in freezing tolerance, which can have important consequences for individual plants all the way up to the ecosystem-level. Freezing temperatures following a warm spell can result in plant damage or even death (Ludlum, 1968; Mock et al., 2007). It can take 16-38 days for trees to refoliate after a spring freeze (Augspurger, 2009, 2013; Gu et al., 2008; Menzel et al., 2015), which can detrimentally affect crucial processes such as carbon uptake and nutrient cycling (Hufkens et al., 2012; Klosterman et al., 2018; Richardson et al., 2013). Additionally, plants can suffer greater longterm effects from the loss of photosynthetic tissue through impacts on multiple years of growth, reproduction, and canopy development (Vitasse et al., 2014; Xie et al., 2015). For these reasons, we focus primarily on spring freeze risk for the vegetative phases, specifically between budburst and leafout, when vegetative tissues are most at risk of damage.

\section{Current metrics of false spring}

Currently researchers use several methods to define a false spring. A common definition is fundamentally empirical and describes a false spring as having two phases: rapid vegetative growth prior to a freeze and a post-freeze setback (Gu et al., 2008). However, as data on tissue damage is often lacking, most definitions do not require it. Other definitions focus on temperatures in the spring that are specific to certain regions (e.g., in Augspurger, 2013, false spring for the Midwestern United States is defined as a warmer than average March, a freezing April, and enough growing degree days between budburst and the last freeze date). A widely used definition integrates a mathematical equation to quantify a false spring event. This equation, known as a False Spring Index (FSI), signifies the likelihood of damage to occur from a late spring freeze. Currently, FSI is evaluated annually by the day of budburst and the day of last

This article is protected by copyright. All rights reserved. 
spring freeze (often calculated at $-2.2^{\circ} \mathrm{C}$, Schwartz1993) through the simple equation (Marino et al., 2011):

$$
\text { FSI = Day of Year (Last Spring Freeze) - Day of Year (Budburst) }
$$

Negative values indicate no-risk situations, whereas a damaging FSI is currently defined to be seven or more days between budburst and the last freeze date (Equation 1) (Peterson \& Abatzoglou, 2014). This index builds off our fundamental understanding that cold hardiness is low following budburst (i.e., the seven-day threshold attempts to capture that leaf tissue is at high risk of damage from frost in the period after budburst but before full leafout), and, by requiring only data on budburst and temperatures, this index can estimate where and when false springs occurred (or will occur) without any data on tissue damage.

\section{Measuring false spring in one temperate plant community}

To demonstrate how the FSI definition works-and is often used-we applied it to data from the Harvard Forest Long-term Ecological Research program in Massachusetts. We selected this site as it has been well monitored for spring phenology through multiple methods for several years. While at the physiological level, frost damage is most likely to occur between budburst and leafout, data on the exact timing of these two events are rarely available and surrogate data are often used to capture 'spring onset' (i.e., initial green-up) at the community level. We applied three commonly used methods to calculate spring onset: long-term ground observational data (O’Keefe, 2014), PhenoCam data (Richardson, 2015), and USA National Phenology Network's (USA-NPN) Extended Spring Index (SI-x) "First Leaf - Spring Onset" data (USA-NPN, 2016). These three methods for spring onset values require different levels of effort and are-thusvariably available for other sites. The local ground observational data (O'Keefe, 2014)— available at few sites-require many hours of personal observation, but comes the closest to estimating budburst and leafout dates. PhenoCam data require only the hours to install and maintain a camera observing the canopy, then process the camera data to determine canopy

This article is protected by copyright. All rights reserved. 
color dynamics over seasons and years. Finally, SI-x data can be calculated for most temperate sites, as the index was specifically designed to provide an available, comparable estimate of spring onset across sites. Once calculated for this particular site we inputted our three estimates of spring onset into the FSI equation (Equation 1) to determine the FSI from 2008 to 2014 (Figure 2).

Each methodology rendered different FSI values, suggesting different false spring damage for the same site over the same years. For most years, the observational FSI and PhenoCam FSI are about 10-15 days lower than the SI-x data. This is especially important for 2008, when the SI-x data and observational data indicate a false spring year, whereas the PhenoCam data do not. In 2012, the observational data and PhenoCam data diverge slightly and the PhenoCam FSI is over 30 days less than the SI-x value.

The reason for these discrepancies is that each method effectively evaluates spring onset by integrating different attributes such as age, species or functional group. Spring phenology in temperate forests typically progresses by functional group: understory species and younger trees tend to initiate budburst first, whereas larger canopy species start later in the season (Richardson \& O’Keefe, 2009; Xin, 2016). The different FSI values determined in Figure 2 exemplify the differences in functional group spring onset dates and illustrate variations in forest demography and phenology. While the SI-x data (based on observations of early-active shrub species, especially including the-non-native to Massachusetts-species lilac, Syringa vulgaris) may best capture understory dynamics, the PhenoCam and observational FSI data integrate over larger canopy species, which burst bud later and thus are at generally lower risk of false springs. Such differences are visible each year, as the canopy-related metrics show lower risk, but are especially apparent in 2012. In 2012, a false spring event was reported through many regions of the US due to warm temperatures occurring in March (Ault et al., 2015). These high temperatures would most likely have been too early for larger canopy species to burst bud

This article is protected by copyright. All rights reserved. 
but they would have affected smaller understory species, as is seen by the high risk of the SI-X FSI in Figure 2.

Differing FSI estimated from our three metrics of spring onset for the same site and years highlight variation across functional groups, which FSI work currently ignores — instead using one metric of spring onset (often from SI-x data, which is widely available) and assuming it applies to the whole community of plants (Allstadt et al., 2015; Marino et al., 2011; Mehdipoor \& Zurita-Milla, 2017; Peterson \& Abatzoglou, 2014). As the risk of a false spring varies across habitats and functional groups (Martin et al., 2010) one spring onset date cannot be used as an effective proxy for all species and researchers should more clearly align their study questions and methods. FSI using such estimates as the SI-x may discern large-scale basic trends across space or years, but require validation with ground observations to be applied to any particular location or functional group of species.

Ideally researchers should first assess the forest demographics and functional groups relevant to their study question, then select the most appropriate method to estimate the date of budburst to determine if a false spring could have occurred. This, however, still ignores variation in the date of leafout (when cold tolerance increases slightly). Further, considering different functional groups is unlikely to be enough for robust predictions in regards to level of damage from a false spring, especially for ecological questions that operate at finer spatial and temporal scales. For many research questions-as we outline below-it will be important to develop false spring metrics that integrate species differences within functional groups, by considering the tolerance and avoidance strategies that species have evolved to mitigate false spring effects.

This article is protected by copyright. All rights reserved. 


\section{Improving false spring definitions}

\section{Integrating avoidance and tolerance strategies}

While most temperate woody species use cold hardiness to tolerate low winter temperatures, species vary in how they minimize spring freeze damage through two major strategies: tolerance and avoidance. Many temperate forest plants employ various morphological or physiological traits to be more frost tolerant. Some species have increased 'packability' of leaf primordia in winter buds which may permit more rapid leafout (Edwards et al., 2017) and thus shorten the exposure time of less resistant tissues. Other species have young leaves with more trichomes, which protect leaf tissue from herbivory and additionally may act as a buffer against hard or radiative frosts (Agrawal et al., 2004; Prozherina et al., 2003). Species living in habitats with drier winters develop shoots and buds with decreased water content, which makes the buds more tolerant to drought and also to false spring events (Beck et al., 2007; Hofmann \& Bruelheide, 2015; Kathke \& Bruelheide, 2011; Morin et al., 2007; Muffler et al., 2016; Norgaard Nielsen \& Rasmussen, 2009; Poirier et al., 2010). These strategies are probably only a few of the many ways plants avoid certain types of spring frost damage, thus more studies are needed to investigate the interplay between morphological and physiological traits and false spring tolerance.

Rather than being more tolerant of spring freezing temperatures, many species have evolved to avoid frosts by bursting bud later in the spring, well past the last frost event. Such species may lose out on early access to resources, but benefit from rarely, if ever, losing tissue to false spring events. They may further benefit from not needing traits related to frost tolerance (Lenz et al., 2013).

The difference in budburst timing across temperate deciduous woody species-which effectively allows some species to avoid false springs-is determined by their responses to three environmental cues that initiate budburst: low winter temperatures (chilling), warm

This article is protected by copyright. All rights reserved. 
spring temperatures (forcing), and increasing photoperiods (Chuine, 2010). The evolution of these three cues and their interactions have permitted temperate plant species to occupy more northern ecological niches (Kollas et al., 2014) and decrease the risk of false spring damage for all species (Charrier et al., 2011). Species that burst bud late are expected to have high requirements of chilling, forcing and/or photoperiod. For example, the combination of a high chilling and a spring forcing requirement (that is, a species that requires long periods of cool temperatures to satisfy a chilling requirement before responding to any forcing conditions) will avoid bursting bud during periods of warm temperatures too early due to insufficient chilling (Basler \& Körner, 2012). An additional photoperiod requirement for budburst can also allow species to avoid false springs. Species with strong photoperiod cues have limited responses to spring forcing until a critical daylength is met, and thus are unlikely to have large advances in budburst with warming. Thus, as long as the critical daylength is past freeze events, these species will evade false spring events (Basler \& Körner, 2014).

Given the diverse array of spring freezing defense mechanisms, improved metrics of false spring events would benefit from a greater understanding of avoidance and tolerance strategies across species, especially under a changing climate. If research could build a framework to help classify species into what strategy they employ, estimates of false spring could quickly identify some species that effectively are never at risk of false spring events versus those that more commonly experience false springs. Of this latter group, specific strategies or traits may then help define which species will see the greatest changes in false spring events with climate change. For example, species that currently avoid false springs through high chilling requirements may see the effectiveness of this strategy erode with warming winters (Montwé et al., 2018).

Alternatively, for species that tolerate false spring through a rapid budburst to leafout phase, climate change may alter the rate of this phase and thus make some species more or less vulnerable.

This article is protected by copyright. All rights reserved. 


\section{Integrating phenological cues to predict vegetative risk}

Understanding what determines the timing of budburst and the length of time between budburst and leafout is essential for predicting the level of damage from a false spring event. The timing between these phenophases (budburst to leafout), which we refer to as the duration of vegetative risk (Figure 3), is a critical area of future research. Currently research shows there is significant variation across species in their durations of vegetative risk, but basic information, such as whether early-budburst species and/or those with fewer morphological traits to avoid freeze damage have shorter durations of vegetative risk compared to other species, is largely unknown, but important for improved forecasting. With spring advancing, species that have shorter durations of vegetative risk would avoid more false springs compared to those that have much longer durations of vegetative risk, especially among species that burst bud early. This hypothesis, however, assumes the duration of vegetative risk will be constant with climate change, which seems unlikely as both phenophases are shaped by environmental cues. The duration of vegetative risk is therefore best thought of as a species-level trait with potentially high variation determined by environmental conditions. Understanding the various physiological and phenological mechanisms that determine budburst and leafout across species will be important for improved metrics of false spring, especially for species- and/or sitespecific studies.

Decades of research on phenology provide a starting point to understand how the environment controls the duration of vegetative risk across species. As reviewed above, the three major cues that control budburst (e.g. low winter temperatures, warm spring temperatures, and increasing photoperiods, Chuine, 2010) play a dominant role. Comparatively fewer studies have examined all three cues for leafout, but work to date suggests both forcing and photoperiod play major roles (Basler \& Körner, 2014; Flynn \& Wolkovich, 2018). The most useful research though would examine both budburst and leafout at once. Instead, most phenological studies currently

This article is protected by copyright. All rights reserved. 
focus on one phenophase (i.e., budburst or leafout) making it difficult to test how the three phenological cues, and their interactions, affect the duration of vegetative risk.

With data in hand, phenological cues can provide a major starting point for predicting how climate change will alter the duration of vegetative risk. Robust predictions will require more information, especially the emissions scenario realized over coming decades (IPCC, 2015), but some outcomes with warming are more expected than others. For example, higher temperatures are generally expected to increase the total forcing and decrease the total chilling over the course of the fall to spring in many locations, as well as to trigger budburst at times of the year when daylength is shorter. Using data from a recent study that manipulated all three cues and measured budburst and leafout (Flynn \& Wolkovich, 2018) shows that any one of these effects alone can have a large impact on the duration of vegetative risk (Figure 4): more forcing shortens it substantially (-15 to -8 days), while shorter photoperiods and less chilling increase it to a lesser extent ( +3 to 9 days). Together, however, the expected shifts generally shorten the duration of vegetative risk by 4-13 days, both due to the large effect of forcing and the combined effects of multiple cues. How shortened the risk period is, however, varies strongly by species and highlights how climate change may speed some species through this high risk period, but not others. Additionally, as our results are for a small set of species we expect other species may have more diverse responses, as has already been seen in shifts in phenology with warming (Cleland et al., 2006; Fu et al., 2015; Xin, 2016).

These findings highlight the need for further studies on the interplay among chilling, forcing, and photoperiod cues and the duration of vegetative risk across species. This is especially true for species occupying ecological niches more susceptible to false spring events; even if warming causes a shortened duration of vegetative risk for such species, the related earlier budburst dates could still lead to greater risk of false spring exposure.

Studies aiming to predict species shifts across populations (e.g., across a species' range) will also need much more information on how a single species' budburst and leafout timing vary across

This article is protected by copyright. All rights reserved. 
space. Research to date has studied only a handful of species and yielded no patterns that can be easily extrapolated to other species or functional groups. Some studies have investigated how phenological cues for budburst vary across space, including variation across populations, by using latitudinal gradients (Gauzere et al., 2017; Søgaard et al., 2008; Way \& Montgomery, 2015; Zohner et al., 2016), which indicates that more southern populations tend to rely on photoperiod more than northern populations. Other studies have examined distance from the coast (see Aitken \& Bemmels, 2015; Harrington \& Gould, 2015; Myking \& Skroppa, 2007), and some have found that it is a stronger indicator of budburst timing than latitude (Myking \& Skroppa, 2007), with populations further inland initiating budburst first, whereas those closer to the coast burst bud later in the season. Changes in chilling requirements for budburst have been repeatedly documented to vary with distance from the coast, and appear predictable based on local climate variation (Campbell \& Sugano, 1979; Howe et al., 2003).

\section{Integrating predictable regional differences in false spring risk}

Understanding the environmental cues that determine the timing and duration of vegetative risk would provide a major step forward in improving metrics of false spring, but then must be combined with a nuanced appreciation of climate. Research to date (Hänninen \& Tanino, 2011; Savolainen et al., 2007; Vitasse et al., 2009) highlights the interplay of species cues with a specific location's climate, especially its extremes (Jochner et al., 2011; Reyer et al., 2013). Climate regime extremes (e.g., seasonal trends, annual minima and annual maxima) vary across regions and are expected to shift dynamically in the future: as climatic regimes are altered by climate change, false spring risk could vary in intensity across regions and time (i.e., regions currently at high risk of false spring damage could become low-risk regions in the future and vice versa). To highlight this, we analyzed five archetypal regions across North America and Europe. Through the use of both phenology (Soudani et al., 2012; Schaber \& Badeck, 2005; USANPN, 2016; White et al., 2009) and climate data (from the NOAA Climate Data Online tool,

This article is protected by copyright. All rights reserved. 
NOAA, 2017) we determined the number of false springs (i.e., temperatures at $-2.2^{\circ} \mathrm{C}$ or below) for each region. Here, we used the FSI equation, which can help understand the interplay of varying climate regimes and phenology at a cross-regional scale; we tallied the number of years when FSI was positive. We found that some regions experienced harsher winters and greater temperature variability throughout the year (Figure 5, e.g., Maine, USA), and these more variable regions often have a much higher risk of false spring than others (Figure 5, e.g., Lyon, France). Here FSI was a valuable resource to elucidate the regional differences in false spring risk, but for useful projections these estimates should be followed up with more refined data (see The future of false spring research below).

Understanding and integrating spatiotemporal effects and regional differences when investigating false spring risk—especially for studies at regional or larger spatial scales—would improve predictions as climate change progresses. As we have discussed above, such differences depend both on the local climate, the local species and the cues for each species at that location. Both single- and multi-species studies will need to integrate these multiple layers of variation, as different species, within the same location can exhibit different sensitivities to the three cues (Basler \& Körner, 2012; Laube et al., 2013), and as a single species may have varying cues across space. Based on cues alone then, different regions may have different durations of vegetative risk for the same species (Caffarra \& Donnelly, 2011; Partanen, 2004; Vihera-aarniio et al., 2006), and accurate predictions will need to integrate cue and climatic variation across space.

\section{The future of false spring research}

With climate change, more researchers across diverse fields and perspectives are studying false springs. Simplified metrics, such as the FSI, have helped to understand how climate change may alter false springs now and in the future. They have helped estimate potential damage and, when combined with methods that can assess tissue loss (e.g., PhenoCam images can capture This article is protected by copyright. All rights reserved. 
initial greenup, defoliation due to frost or herbivory, then refoliation, Richardson et al., 2018), have documented the prevalence of changes to date. Related work has shown that duration of vegetative risk can be extended if a freezing event occurs during the phenophases between budburst and full leafout (Augspurger, 2009), which could result in exposure to multiple frost events in one season. Altogether they have provided an important way to meld phenology and climate data to understand impacts on plant growth and advance the field (Allstadt et al., 2015; Ault et al., 2015; Liu et al., 2018; Peterson \& Abatzoglou, 2014). As research in this area grows, however, the use of simple metrics to estimate when and where plants experience damage may slow progress in many fields.

As we have outlined above, current false spring metrics depend on the phenological data used, and thus often ignore important variation across functional groups, species, populations, and life-stages - variation that is critical for many types of studies. Many studies in particular use gridded spring-onset data (e.g., SI-x). Studies aiming to forecast false spring risk across a species' range using SI-x data may do well for species similar to lilac (Syringa vulgaris), such as other closely-related shrub species distributed across or near lilac's native southwestern European range. But we expect predictions would be poor for less-similar species. No matter the species, current metrics ignore variation in cues underlying the duration of vegetative risk across space (and, similarly, climate) and assume a single threshold temperature and 7-day window. These deficiencies, however, highlight the simple ways that metrics such as FSI can be adapted for improved predictions. For example, researchers interested in false spring risk across a species range can gather data on freezing tolerance, the environmental cues that drive the variation in the duration of vegetative risk and whether those cues vary across populations, then adjust the FSI or similar metrics. Indeed, given the growing use of the SI-x for false spring estimates research into the temperature thresholds and cues for budburst and leafout timing of Syringa vulgaris could refine FSI estimates using SI-x.

This article is protected by copyright. All rights reserved. 
Related to range studies, studies of plant life history will benefit from more-specialized metrics of false spring. Estimates of fitness consequences of false springs at the individual- populationor species-levels must integrate over important population and life-stage variation. In such cases, careful field observational and lab experimental data will be key. Through such data, researchers can capture the variations in temperature thresholds, species- and lifestage-specific tolerance and avoidance strategies and climatic effects, and more accurately measure the level of damage.

Though time-consuming, we suggest research to discover species $x$ life-stage $x$ phenophase specific freezing tolerances and related cues determining the duration of vegetative risk will make major advances in fundamental and applied science. Such studies can help determine at which life stages and phenophases false springs have important fitness consequences, and whether tissue damage from frost for some species $x$ life stages actually scales up to minimal fitness effects. As more data are gathered, researchers can test whether there are predictable patterns across functional groups, clades, life history strategies, or related morphological traits. Further, such work would form the basis to predict how future plant communities may be reshaped by changes in false spring events with climate change. False spring events could have large-scale consequences on forest recruitment, and potentially impact juvenile growth and forest diversity, but predicting this is another research area that requires far more and improved species-specific data.

We suggest most studies at the individual to community levels need far more complex metrics of false spring to make major progress, however, simple metrics of false spring may be appropriate for a suite of studies at ecosystem-level scales. Single-metric approaches, such as the FSI, are better than not including spring frost risk in relevant studies. Thus, these metrics could help improve many ecosystem models, including land surface models (Foley et al., 1998; Moorcroft et al., 2001; Prentice et al., 1992; Thornton et al., 2005). In such models, SI-x combined with FSI could provide researchers with predicted shifts in frequency of false springs

This article is protected by copyright. All rights reserved. 
under emission scenarios. Some models, such as the Ecosystem Demography (ED) and the BIOME-BGC models, already integrate phenology data by functional group (Kim et al., 2015; Moorcroft et al., 2001; Thornton et al., 2005), by adding last freeze date information, FSI could then be evaluated to predict false spring occurrence with predicted shifts in climate. By including even a simple proxy for false spring risk, models, including ED and BIOME-BGC, could better inform predicted range shifts. As such models often form a piece of global climate models (Yu et al., 2016), incorporating false spring metrics could refine estimates of future carbon budgets and related shifts in climate. As more data help to refine our understanding of false spring damage for different functional groups, species and populations, these new insights can in turn help improve false spring metrics used for ecosystem models. Eventually earth system models could include feedbacks between how climate shifts alter false spring events, which may reshape forest demography and, in turn, alter the climate itself.

\section{Acknowledgments}

We thank D. Buonaiuto, W. Daly, A. Ettinger, I. Morales-Castilla and three reviewers for comments and insights that improved the manuscript.

This article is protected by copyright. All rights reserved. 


\section{References}

Agrawal AA, Conner JK, Stinchcombe JR (2004) Evolution of plant resistance and tolerance to frost damage. Ecology Letters, 7, 1199-1208. 10.1111/j.1461-0248.2004.00680.x.

Aitken SN, Bemmels JB (2015) Time to get moving: assisted gene flow of forest trees. Evolutionary Applications, 9, 271-290. 10.1111/eva.12293.

Allstadt AJ, Vavrus SJ, Heglund PJ, Pidgeon AM, Wayne E, Radeloff VC (2015) Spring plant phenology and false springs in the conterminous U. S. during the 21st century. Environmental Research Letters (submitted), 10, 104008. 10.1088/17489326/10/10/104008.

Augspurger CK (2009) Spring 2007 warmth and frost: Phenology, damage and refoliation in a temperate deciduous forest. Functional Ecology, 23, 1031-1039. 10.1111/j.13652435.2009.01587.x.

Augspurger CK (2013) Reconstructing patterns of temperature, phenology, and frost damage over 124 years: Spring damage risk is increasing. Ecology, 94, 41-50. 10.1890/12-0200.1.

Ault TR, Henebry GM, de Beurs KM, Schwartz MD, Betancourt JL, Moore D (2013) The false spring of 2012, earliest in North American record. Eos, Transactions American Geophysical Union, 94, 181-182. 10.1002/2013E0200001.

Ault TR, Schwartz MD, Zurita-Milla R, Weltzin JF, Betancourt JL (2015) Trends and natural variability of spring onset in the coterminous United States as evaluated by a new gridded dataset of spring indices. Journal of Climate, 28, 8363-8378. 10.1175/JCLI-D-14-00736.1.

Barker D, Loveys B, Egerton J, Gorton H, Williams W, Ball M (2005) $\mathrm{CO}_{2}$ Enrichment predisposes foliage of a eucalypt to freezing injury and reduces spring growth. Plant, Cell and Environment, 28, 1506-1515.

This article is protected by copyright. All rights reserved. 
Barlow K, Christy B, O’Leary G, Riffkin P, Nuttall J (2015) Simulating the impact of extreme heat and frost events on wheat crop production: A review. Field Crops Research, 171, 109-119.

Basler D, Körner C (2012) Photoperiod sensitivity of bud burst in 14 temperate forest tree species. Agricultural and Forest Meteorology, 165, 73-81.

10.1016/j.agrformet.2012.06.001.

Basler D, Körner C (2014) Photoperiod and temperature responses of bud swelling and bud burst in four temperate forest tree species. Tree Physiology, 34, 377-388. 10.1093/treephys/tpu021.

Beck EH, Fettig S, Knake C, Hartig K, Bhattarai T (2007) Specific and unspecific responses of plants to cold and drought stress. Journal of Biosciences, 32, 501-510.

Caffarra A, Donnelly A (2011) The ecological significance of phenology in four different tree species: Effects of light and temperature on bud burst. International Journal of Biometeorology, 55, 711-721. 10.1007/s00484-010-0386-1.

Campbell RK, Sugano AI (1979) Genecology of bud-burst phenology in Douglas-Fir: response to flushing temperature and chilling. Botanical Gazette, 140, 223-231. URL http://www.jstor.org/stable/2473722.

CaraDonna PJ, Bain JA (2016) Frost sensitivity of leaves and flowers of subalpine plants is related to tissue type and phenology. Journal of Ecology, 104, 55-64. 10.1111/13652745.12482.

Charrier G, Bonhomme M, Lacointe A, Améglio T (2011) Are budburst dates, dormancy and cold acclimation in walnut trees (Juglans regia L.) under mainly genotypic or environmental control? International Journal of Biometeorology, 55, 763-774. 10.1007/s00484-0110470-1.

This article is protected by copyright. All rights reserved. 
Chuine I (2010) Why does phenology drive species distribution? Philosophical Transactions of the Royal Society B: Biological Sciences, 365, 3149-3160. 10.1098/rstb.2010.0142.

Cleland E, Chiariello N, Loarie S, Mooney H, Field C (2006) Diverse responses of phenology to global changes in a grassland ecosystem. PNAS, 103, 13740-13744.

Edwards EJ, Chatelet DS, Spriggs EL, Johnson ES, Schlutius C, Donoghue MJ (2017) Correlation, causation, and the evolution of leaf teeth: A reply to Givnish and Kriebel. Am J Bot, 104, 509-515. 10.3732/ajb.1700075.

Estiarte M, Peñuelas J (2015) Alteration of the phenology of leaf senescence and fall in winter deciduous species by climate change: effects on nutrient proficiency. Global Change Biology, 21, 1005-1017. doi:10.1111/gcb.12804.

Flynn DFB, Wolkovich EM (2018) Temperature and photoperiod drive spring phenology across all species in a temperate forest community. New Phytologist, 219. 10.1111/nph.15232.

Foley JA, Levis S, Prentice IC, Pollard D, Thompson SL (1998) Coupling dynamic models of climate and vegetation. Global Change Biology, 4, 561-579. doi:10.1046/j.13652486.1998.t01-1-00168.x.

Fu YH, Zhao H, Piao S, et al. (2015) Declining global warming effects on the phenology of spring leaf unfolding. Nature, 526, 104-107. 10.1038/nature15402.

Gauzere J, Delzon S, Davi H, Bonhomme M, Garcia de Cortazar-Atauri I, Chuine I (2017) Integrating interactive effects of chilling and photoperiod in phenological process-based models. A case study with two European tree species: Fagus sylvatica and Quercus petraea. Agricultural and Forest Meteorology, 244-255, 9-20.

Gu L, Hanson PJ, Post WM, et al. (2008) The 2007 Eastern US spring freeze: Increased cold damage in a warming world. BioScience, 58, 253. 10.1641/B580311.

This article is protected by copyright. All rights reserved. 
Hänninen H, Tanino K (2011) Tree seasonality in a warming climate. Trends in Plant Science, 16, 412 - 416. https://doi.org/10.1016/j.tplants.2011.05.001. URL

http://www.sciencedirect.com/science/article/pii/s13601385110009

99.

Harrington CA, Gould PJ (2015) Tradeoffs between chilling and forcing in satisfying dormancy requirements for Pacific Northwest tree species. Frontiers in Plant Science, 6. 10.3389/fpls.2015.00120.

Heide 0, Prestrud A (2005) Low temperature, but not photoperiod, controls growth cessation and dormancy induction and release in apple and pear. Tree physiology, 25, 109-114.

Hofmann M, Bruelheide H (2015) Frost hardiness of tree species is independent of phenology and macroclimatic niche. Journal of Biosciences, 40, 147-157. 10.1007/s12038-015-95059.

Howe GT, Aitken SN, Neale DB, Jermstad KD, Wheeler NC, Chen TH (2003) From genotype to phenotype: unraveling the complexities of cold adaptation in forest trees. Canadian Journal of Botany, 81, 1247-1266. 10.1139/b03-141.

Hufkens K, Friedl MA, Keenan TF, Sonnentag O, Bailey A, O’Keefe J, Richardson AD (2012) Ecological impacts of a widespread frost event following early spring leaf-out. Global Change Biology, 18, 2365-2377. 10.1111/j.1365-2486.2012.02712.x.

Inouye DW (2000) The ecological and evolutionary significance of frost in the context of climate change. Ecology Letters, 3, 457-463. 10.1046/j.1461-0248.2000.00165.x.

Inouye DW (2008) Effects of climate change on phenology, frost damage, and floral abundance of montane wildflowers. Ecology, 89, 353-362.

IPCC (2015) Climate change 2014: mitigation of climate change, vol. 3. Cambridge University Press.

This article is protected by copyright. All rights reserved. 
Jochner SC, Beck I, Behrendt H, Traidl-Hoffmann C, Menzel A (2011) Effects of extreme spring temperatures on urban phenology and pollen production: a case study in Munich and Ingolstadt.

Kathke S, Bruelheide H (2011) Differences in frost hardiness of two Norway spruce morphotypes growing at Mt. Brocken, Germany. Flora - Morphology, Distribution, Functional Ecology of Plants, 206, 120-126. 10.1016/j.flora.2010.09.007.

Kim Y, Moorcroft PR, Aleinov I, Puma MJ, Kiang NY (2015) Variability of phenology and fluxes of water and carbon with observed and simulated soil moisture in the Ent Terrestrial Biosphere Model (Ent TBM version 1.0.1.0.0). Geoscientific Model Development, 8, 38373865. 10.5194/gmd-8-3837-2015.

Klosterman S, Hufkens K, Richardson AD (2018) Later springs green-up faster: the relation between onset and completion of green-up in deciduous forests of North America. International Journal of Biometeorology. 10.1007/s00484-018-1564-9.

Knudson W (2012) The economic impact of the spring's weather on the fruit and vegetable

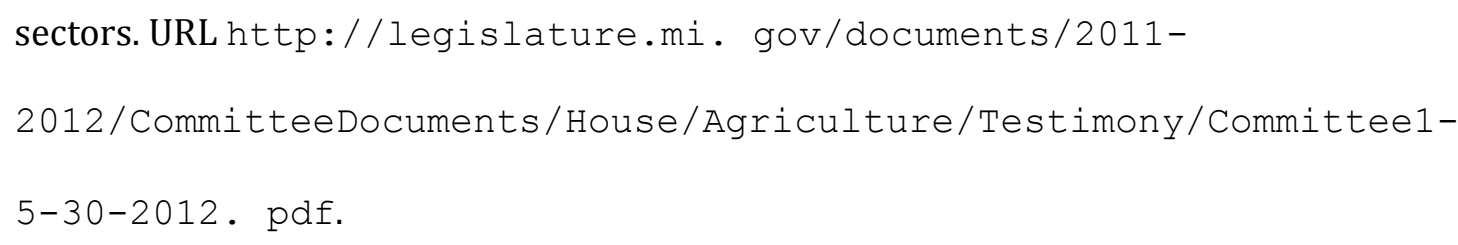

Kollas C, Körner C, Randin CF (2014) Spring frost and growing season length co-control the cold range limits of broad-leaved trees. Journal of Biogeography, 41, 773-783. 10.1111/jbi.12238.

Körner C (2012) Alpine treelines: functional ecology of the global high elevation tree limits. Springer Science \& Business Media.

This article is protected by copyright. All rights reserved. 
Laube J, Sparks TH, Estrella N, Höfler J, Ankerst DP, Menzel A (2013) Chilling outweighs photoperiod in preventing precocious spring development. Global Change Biology, 20, 170-182. 10.1111/gcb.12360.

Lenz A, Hoch G, Körner C, Vitasse Y (2016) Convergence of leaf-out towards minimum risk of freezing damage in temperate trees. Functional Ecology, 30, 1-11. 10.1111/13652435.12623.

Lenz A, Hoch G, Vitasse Y, Körner C (2013) European deciduous trees exhibit similar safety margins against damage by spring freeze events along elevational gradients. New Phytologist, 200, 1166-1175. 10.1111/nph.12452.

Liu Q, Piao S, Janssens IA, et al. (2018) Extension of the growing season increases vegetation exposure to frost. Nature Communications, 9. 10.1038/s41467-017-02690-y.

Longstroth M (2012) Protect blueberries from spring freezes by using sprinklers. URL

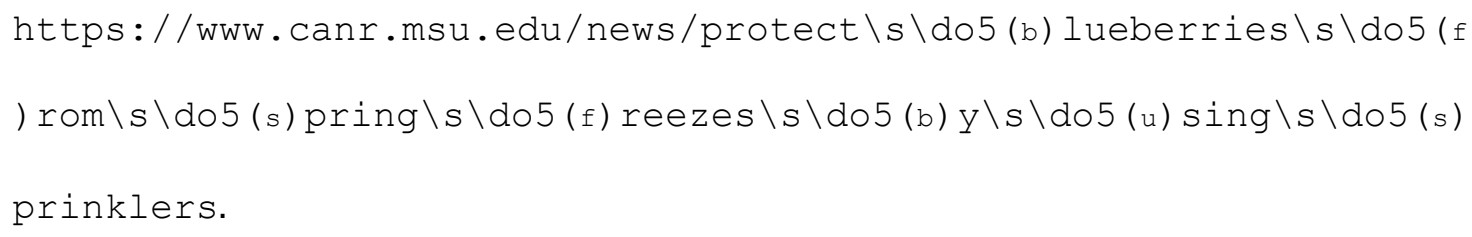

Longstroth M (2013) Assessing frost and freeze damage to flowers and buds of fruit trees. URL

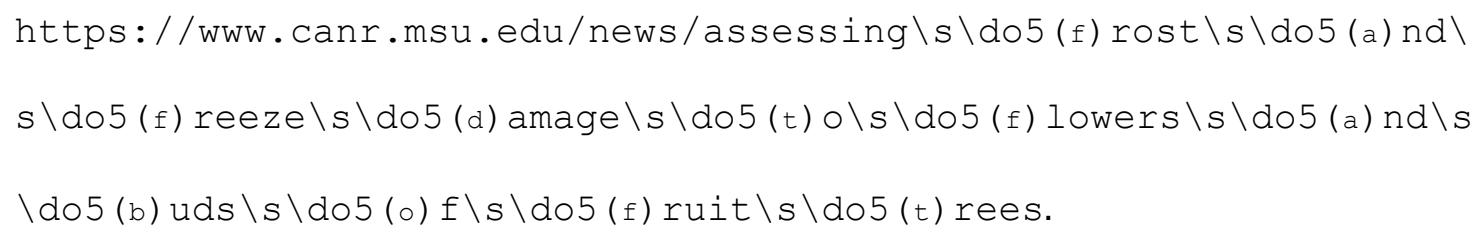

Ludlum DM (1968) Early American Winters: 1604-1820. 3. Boston: American Meteorological Society.

Marino GP, Kaiser DP, Gu L, Ricciuto DM (2011) Reconstruction of false spring occurrences over the southeastern United States, 1901-2007: an increasing risk of spring freeze damage? Environmental Research Letters, 6, 24015. 10.1088/1748-9326/6/2/024015.

This article is protected by copyright. All rights reserved. 
Martin M, Gavazov K, Körner C, Hattenschwiler S, Rixen C (2010) Reduced early growing season freezing resistance in alpine treeline plants under elevated atmospheric $\mathrm{CO}_{2}$. Global Change Biology, 16, 1057-1070. 10.1111/j.1365-2486.2009.01987.x.

Mehdipoor H, Zurita-Milla EIVR (2017) Continental-scale monitoring and mapping of false spring: A cloud computing solution. URL

http://www.geocomputation.org/2017/papers/48.pdf.

Menzel A, Helm R, Zang C (2015) Patterns of late spring frost leaf damage and recovery in a European beech (Fagus sylvatica L.) stand in south-eastern Germany based on repeated digital photographs. Frontiers in Plant Science, 6, 110. 10.3389/fpls.2015.00110.

Mock CJ, Mojzisek J, McWaters M, Chenoweth M, Stahle DW (2007) The winter of 1827-1828 over eastern North America: a season of extraordinary climatic anomalies, societal impacts, and false spring. Climatic Change, 83, 87-115. 10.1007/s10584-006-9126-2.

Montwé D, Isaac-Renton M, Hamann A, Spiecker H (2018) Cold adaptation recorded in tree rings highlights risks associated with climate change and assisted migration. Nature Communications, 9. 10.1038/s41467-018-04039-5.

Moorcroft PR, Hurtt GC, Pacala SW (2001) A method for scaling vegetation dynamics: The Ecosystem Demography Model (ED). Ecological Monographs, 71, 557-585. URL http://www.jstor.org/stable/3100036.

Morin X, Ameglio T, Ahas R, et al. (2007) Variation in cold hardiness and carbohydrate concentration from dormancy induction to bud burst among provenances of three European oak species. Tree Physiology, 27, 817-825.

Muffler L, Beierkuhnlein C, Aas G, Jentsch A, Schweiger AH, Zohner C, Kreyling J (2016) Distribution ranges and spring phenology explain late frost sensitivity in 170 woody

This article is protected by copyright. All rights reserved. 
plants from the Northern Hemisphere. Global Ecology and Biogeography, 25, 1061-1071. 10.1111/geb.12466.

Myking T, Skroppa T (2007) Variation in phenology and height increment of northern Ulmus glabra populations: Implications for conservation. Scandinavian Journal of Forest Research, 22, 369-374.

NOAA (2017) Climate data online search. URL https : / / www . ncdc . noaa . gov/cdoweb/search?datasetid=GHCND.

Norgaard Nielsen CC, Rasmussen HN (2009) Frost hardening and dehardening in Abies procera and other conifers under differing temperature regimes and warm-spell treatments. Forestry, 82, 43-59. 10.1093/forestry/cpn048. URL http://dx.doi.org/10.1093/forestry/cpn048.

O’Keefe J (2014) Phenology of woody species at Harvard Forest since 1990. URL http://harvardforest. fas.harvard. edu:8080/exist/apps/datasets/sh owData.html?id=hf003.

Partanen J (2004) Dependence of photoperiodic response of growth cessation on the stage of development in Picea abies and Betula pendula seedlings. Forest Ecology and Management, 188, 137-148. 10.1016/j.foreco.2003.07.017.

Peterson AG, Abatzoglou JT (2014) Observed changes in false springs over the contiguous United States. Geophysical Research Letters, 41, 2156-2162. 10.1002/2014GL059266.

Poirier M, Lacointe A, Ameglio T (2010) A semi-physiological model of cold hardening and dehardening in walnut stem. Tree Physiology, 30, 1555-1569. 10.1093/treephys/tpq087.

Prentice IC, Cramer W, Harrison SP, Leemans R, Monserud RA, Solomon AM (1992) Special paper: a global biome model based on plant physiology and dominance, soil properties and climate. Journal of biogeography, pp. 117-134.

This article is protected by copyright. All rights reserved. 
Prozherina N, Freiwald V, Rousi M, Oksanen E (2003) Interactive effect of springtime frost and elevated ozone on early growth, foliar injuries and leaf structure of birch (Betula pendula). New Phytologist, 159, 623-636. 10.1046/j.1469-8137.2003.00828.x.

Reyer CP, Leuzinger S, Rammig A, et al. (2013) A plant's perspective of extremes: terrestrial plant responses to changing climatic variability. Global change biology, 19, 75-89.

Richardson A, O’Keefe J (2009) Phenological differences between understory and overstory: a case study using the long-term Harvard Forest records, pp. 87-117. A. Noormets (Ed.), Phenology of Ecosystem Processes, Springer, New York.

Richardson AD (2015) PhenoCam images and canopy phenology at Harvard Forest since 2008. URL http://harvardforest.fas.harvard.edu:8080/exist/apps/datasets/sh owData.html?id=hf158.

Richardson AD, Hufkens K, Milliman T, Frolking S (2018) Intercomparison of phenological transition dates derived from the PhenoCam Dataset V1.0 and MODIS satellite remote sensing. Scientific Reports, 8. 10.1038/s41598-018-23804-6.

Richardson AD, Keenan TF, Migliavacca M, Ryu Y, Sonnentag O, Toomey M (2013) Climate change, phenology, and phenological control of vegetation feedbacks to the climate system. Agricultural and Forest Meteorology, 169, 156 - 173. https://doi.org/10.1016/j.agrformet.2012.09.012.

Sakai A, Larcher W (1987) Frost Survival of Plants. Springer-Verlag.

Sánchez B, Rasmussen A, Porter JR (2013) Temperatures and the growth and development of maize and rice: a review. Global Change Biology, 20, 408-417. 10.1111/gcb.12389.

This article is protected by copyright. All rights reserved. 
Savolainen 0, Pyhäjärvi T, Knürr T (2007) Gene flow and local adaptation in trees. Annual Review of Ecology, Evolution, and Systematics, 38, 595-619.

10.1146/annurev.ecolsys.38.091206.095646.

Schaber J, Badeck FW (2005) Plant phenology in Germany over the 20th century. Regional Environmental Change, 5, 37-46. 10.1007/s10113-004-0094-7.

Schwartz MD (1993) Assessing the onset of spring: A climatological perspective. Physical Geography, 14(6), 536-550.

Søgaard G, Johnsen Ø, Nilsen J, Junttila O (2008) Climatic control of bud burst in young seedlings of nine provenances of Norway spruce. Tree Physiology, 28, 311-320.

Soudani K, Hmimina G, Delpierre N, et al. (2012) Ground-based Network of NDVI measurements for tracking temporal dynamics of canopy structure and vegetation phenology in different biomes. Remote Sensing of Environment, 123, 234-245. 10.1016/j.rse.2012.03.012.

Strimbeck GR, Schaberg PG, Fossdal CG, Schröder WP, Kjellsen TD (2015) Extreme low temperature tolerance in woody plants. Frontiers in Plant Science, $\mathbf{6}$. 10.3389/fpls.2015.00884.

Thornton PE, Running SW, Hunt ER (2005) Biome-BGC: Terrestrial Ecosystem Process Model, Version 4.1.1. 10.3334/ornldaac/805.

USA-NPN (2016) USA National Phenology Network Extended Spring Indices. URL http://dx.doi.org/10.5066/F7XD0ZRK.

Vihera-aarnio A, Hakkinen R, Junttila O (2006) Critical night length for bud set and its variation in two photoperiodic ecotypes of Betula pendula. Tree Physiology, 26, 1013-1018.

Vitasse Y, Delzon S, Bresson CC, Michalet R, Kremer A (2009) Altitudinal differentiation in growth and phenology among populations of temperate-zone tree species growing in a common garden. Canadian Journal of Forest Research, 39, 1259-1269.

This article is protected by copyright. All rights reserved. 
Vitasse Y, Lenz A, Hoch G, Körner C (2014) Earlier leaf-out rather than difference in freezing resistance puts juvenile trees at greater risk of damage than adult trees. Journal of Ecology, 102, 981-988. 10.1111/1365-2745.12251.

Vitra A, Lenz A, Vitasse Y (2017) Frost hardening and dehardening potential in temperate trees from winter to budburst. New Phytologist, 216, 113-123. 10.1111/nph.14698.

Way DA, Montgomery RA (2015) Photoperiod constraints on tree phenology, performance and migration in a warming world. Plant, Cell \& Environment, 38, 1725-1736. 10.1111/pce.12431.

Welling A, Kaikuranta P, Rinne P (1997) Photoperiodic induction of dormancy and freezing tolerance in Betula pubescens. Involvement of ABA and dehydrins. Physiologia Plantarum, 100, $119-125$.

White MA, De Beurs KM, Didan K, et al. (2009) Intercomparison, interpretation, and assessment of spring phenology in North America estimated from remote sensing for 1982-2006. Global Change Biology, 15, 2335-2359. 10.1111/j.1365-2486.2009.01910.x.

Xie Y, Wang X, Silander JA (2015) Deciduous forest responses to temperature, precipitation, and drought imply complex climate change impacts. Proceedings of the National Academy of Sciences, 112, 13585-13590. 10.1073/pnas.1509991112.

Xin Q (2016) A risk-benefit model to simulate vegetation spring onset in response to multidecadal climate variability: Theoretical basis and applications from the field to the Northern Hemisphere. Agriculture and Forest Meteorology, 228-229, 139-163.

Yu M, Wang G, Chen H (2016) Quantifying the impacts of land surface schemes and dynamic vegetation on the model dependency of projected changes in surface energy and water budgets. Journal of Advances in Modeling Earth Systems, 8, 370-386.

This article is protected by copyright. All rights reserved. 
Zohner CM, Benito BM, Svenning JC, Renner SS (2016) Day length unlikely to constrain climatedriven shifts in leaf-out times of northern woody plants. Nature Climate Change, 6, 11201123. 10.1038/nclimate3138.

\section{Figure Captions:}

Figure 1: A comparison of damaging spring freezing temperature thresholds across ecological and agronomic studies. Each study is listed on the vertical axis along with the taxonomic group of focus. Next to the species name is the freezing definition used within that study (e.g., $100 \%$ is $100 \%$ whole plant lethality). Each point is the best estimate recorded for the temperature threshold with standard deviation if indicated in the study.

Figure 2: False Spring Index (FSI) values from 2008 to 2014 vary across methods. To calculate spring onset, we used the USA-NPN Extended Spring Index tool for the USA-NPN FSI values, which are the circles (USA-NPN, 2016), long-term ground observational data for the observed FSI values, which are the triangles (O'Keefe, 2014), and near-surface remote-sensing canopy data for the PhenoCam FSI values, which are the squares (Richardson, 2015). See the Supplement for extended details. The solid grey line at FSI $=0$ indicates a boundary between a likely false spring event or not, with positive numbers indicating a false spring likely occurred and negative numbers indicating a false spring most likely did not occur. The dotted grey line at FSI=7 indicates the seven-day threshold frequently used in false spring definitions, which suggests years with FSI values greater than seven very likely had false spring events.

Figure 3: Differences in spring phenology and false spring risk across two species: Ilex mucronata (L.) and Betula alleghaniensis (Marsh.). We mapped a hypothetical false spring event based on historical weather data and long-term observational phenological data collected at Harvard Forest (O'Keefe, 2014). In this scenario, Ilex mucronata, which bursts bud early and generally has a short period between budburst (squares) and leafout (triangles), would be exposed to a false spring event during its duration of vegetative risk (i.e., from budburst to leafout), whereas Betula alleghaniensis would avoid it entirely (even though it has a longer duration of vegetative risk), due to later budburst.

This article is protected by copyright. All rights reserved. 
Figure 4: Effects of phenological cues on the duration of vegetative risk across three species: Acer pensylvanicum, Fagus grandifolia, and Populus grandidentata (see the Supplement for further details).

'More Forcing' is a $5^{\circ} \mathrm{C}$ increase in spring warming temperatures, 'Shorter Photoperiod' is a 4-hour decrease in photoperiod and 'Less Chilling' is a 30-day decrease in over-winter chilling. Along with the estimated isolated effects, we the show the combined predicted shifts in phenological cues with potential climate change (i.e., more forcing with shorter photoperiod and more forcing with less chilling) and the subsequent shifts in duration of vegetative risk across species. To calculate the combined effects, we added the estimated isolated effects of each cue alone with the interaction effects for the relevant cues for each species.

Figure 5: False spring risk can vary dramatically across regions. Here we show the period when plants are most at risk to tissue loss - between budburst and leafout (upper, lines represent the range with the thicker line representing the interquartile range) and the variation in the number of freeze days $\left(-2.2^{\circ} \mathrm{C}\right)$ (Schwartz, 1993) that occurred on average over the past 50 years for five different sites (lower, bars represent the range, points represent the mean). Data come from USA-NPN SI-x tool (1981-2016), NDVI and remote-sensing, and observational studies (1950-2016) for phenology (Schaber \& Badeck, 2005; Soudani et al., 2012; USA-NPN, 2016; White et al., 2009) and NOAA Climate Data Online tool for climate (from 1950-2016). See the Supplement for further details on methods.

This article is protected by copyright. All rights reserved. 


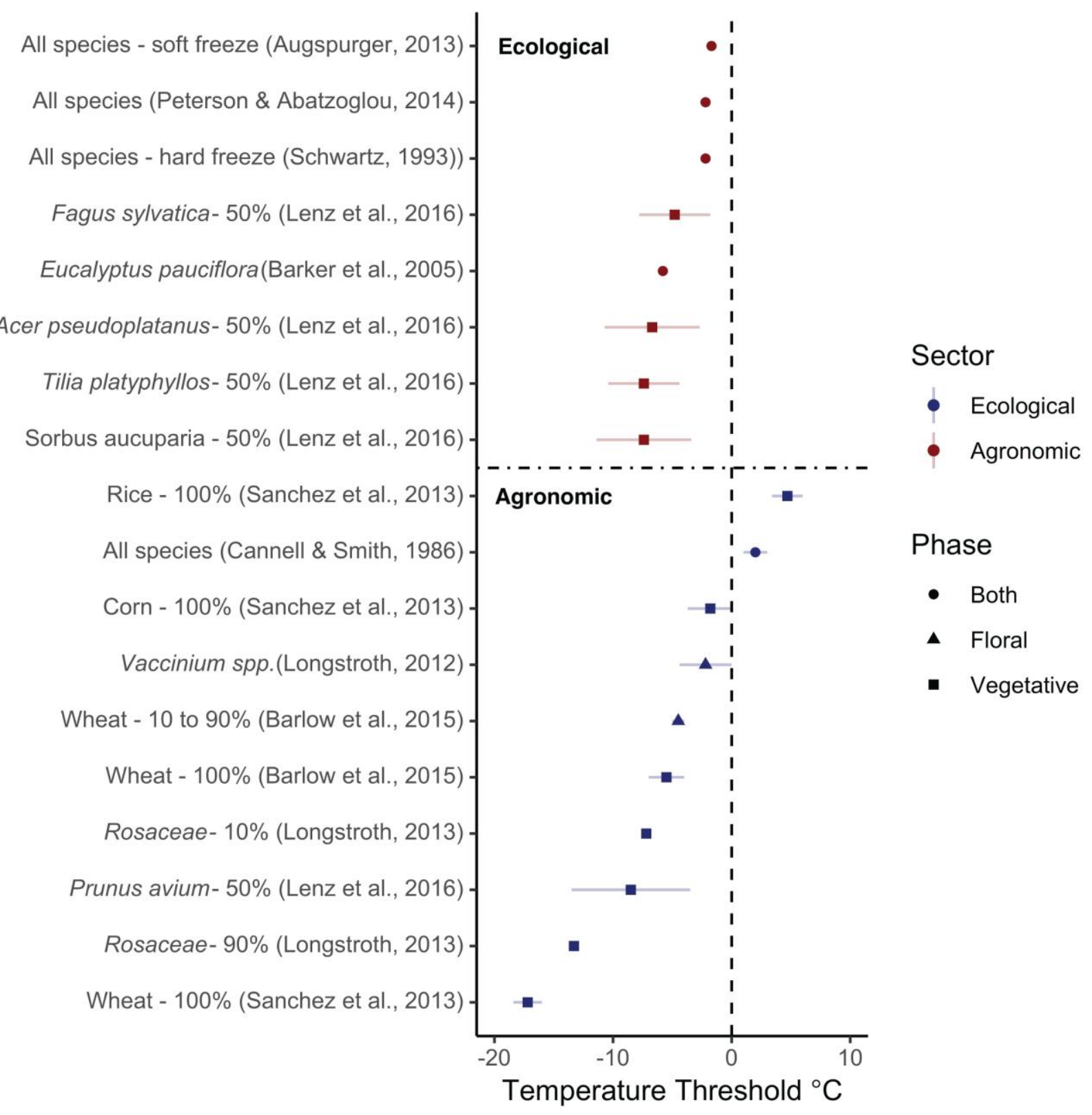

This article is protected by copyright. All rights reserved. 


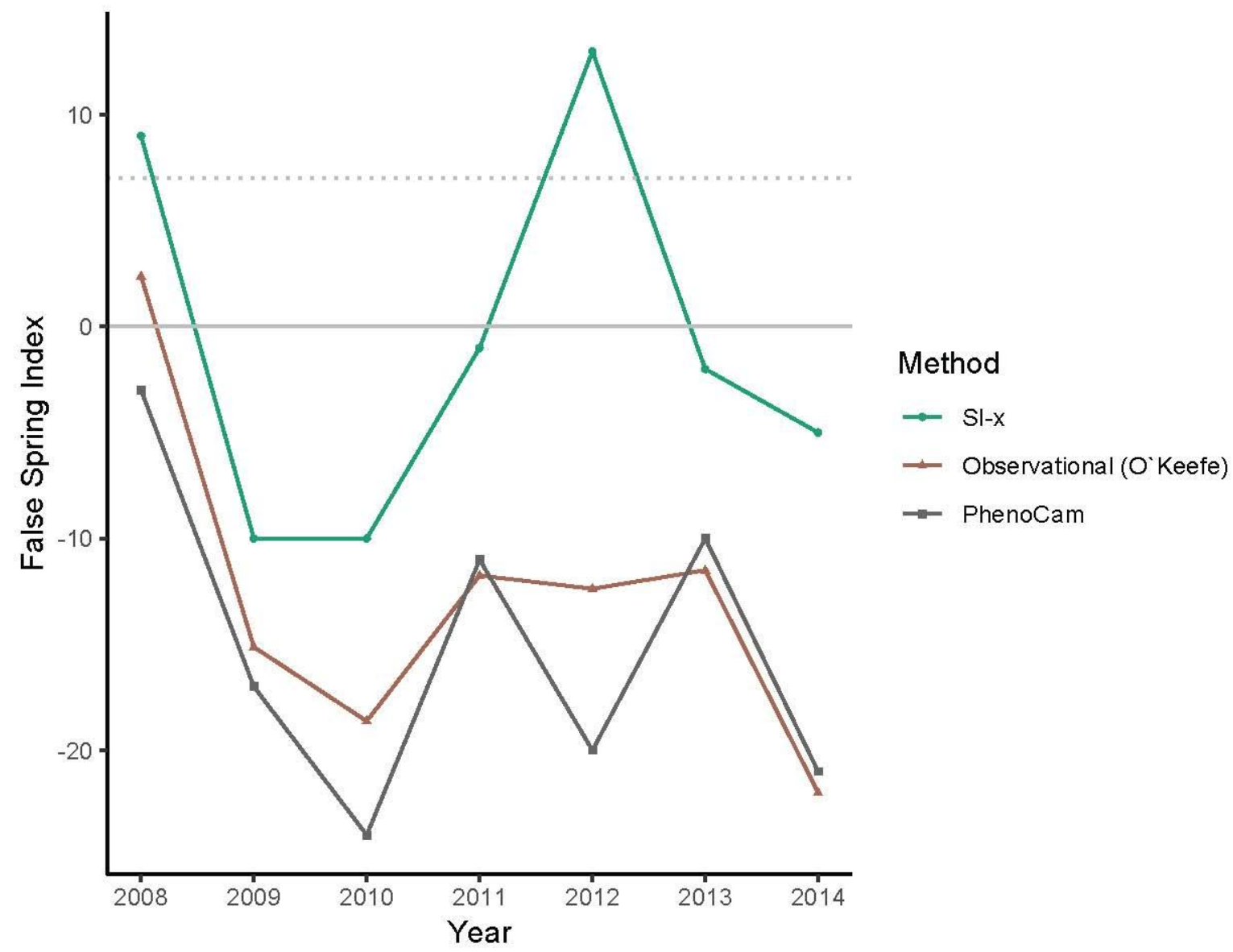

This article is protected by copyright. All rights reserved. 

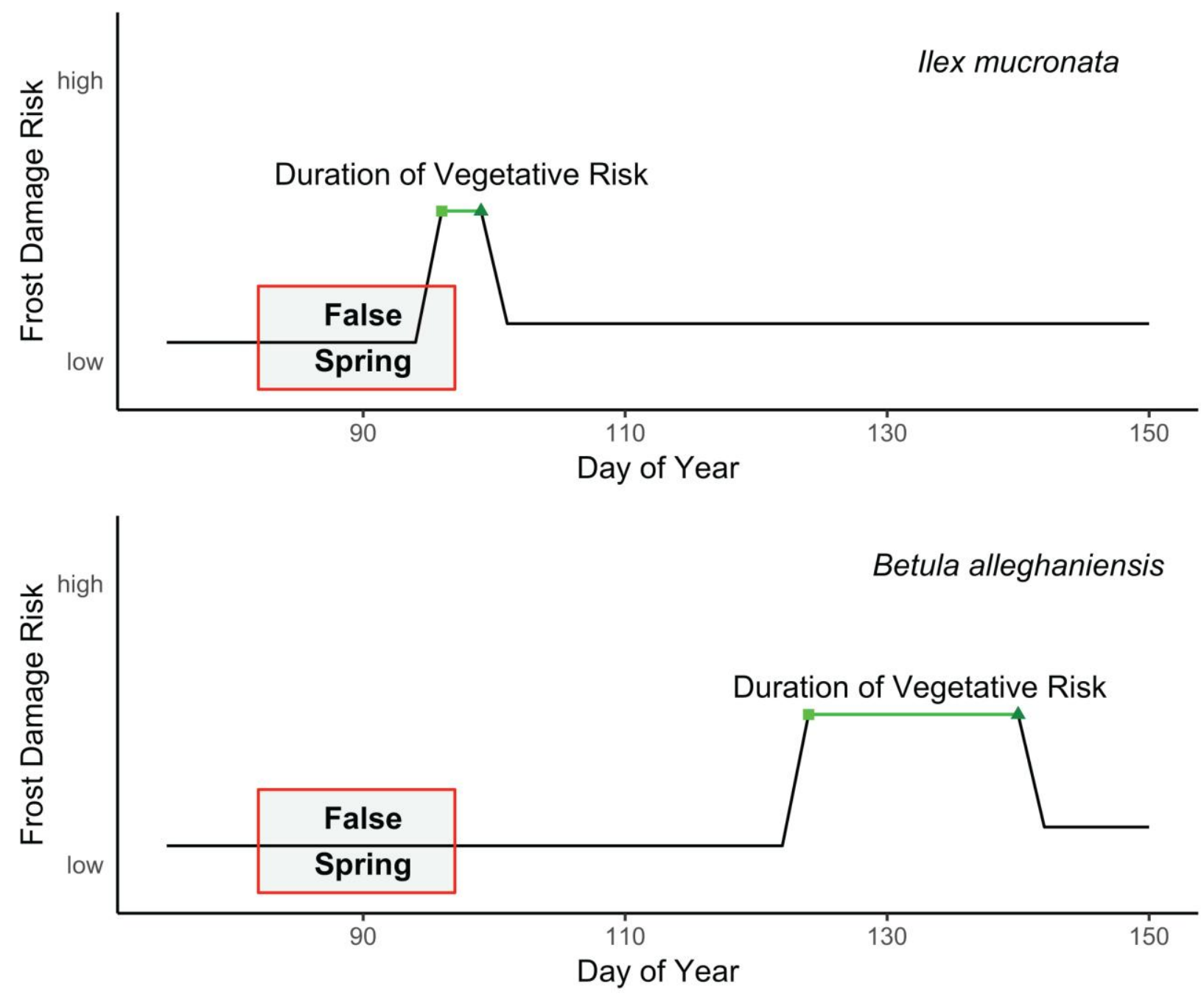

This article is protected by copyright. All rights reserved. 


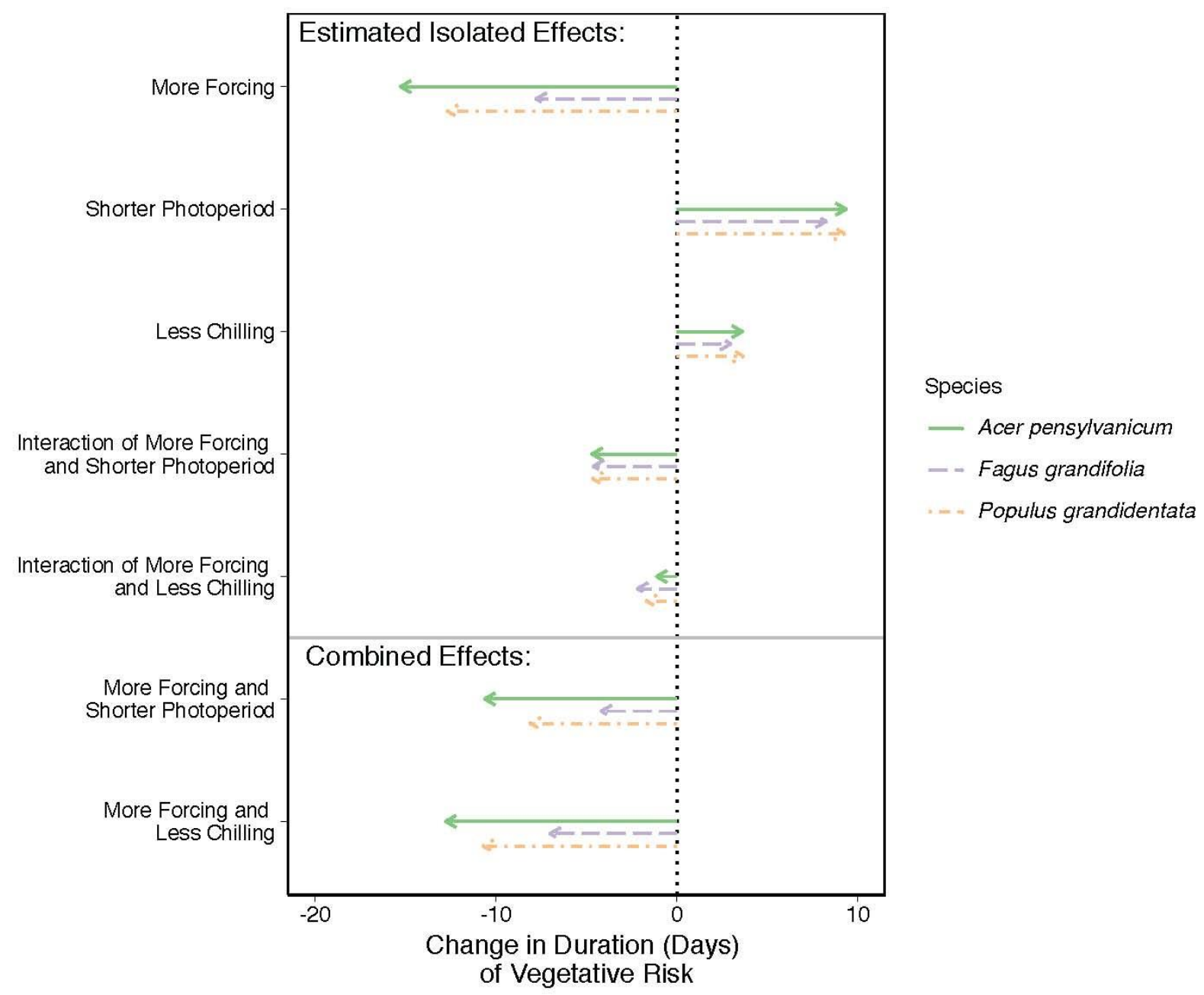

This article is protected by copyright. All rights reserved.

Comment citer ce document 


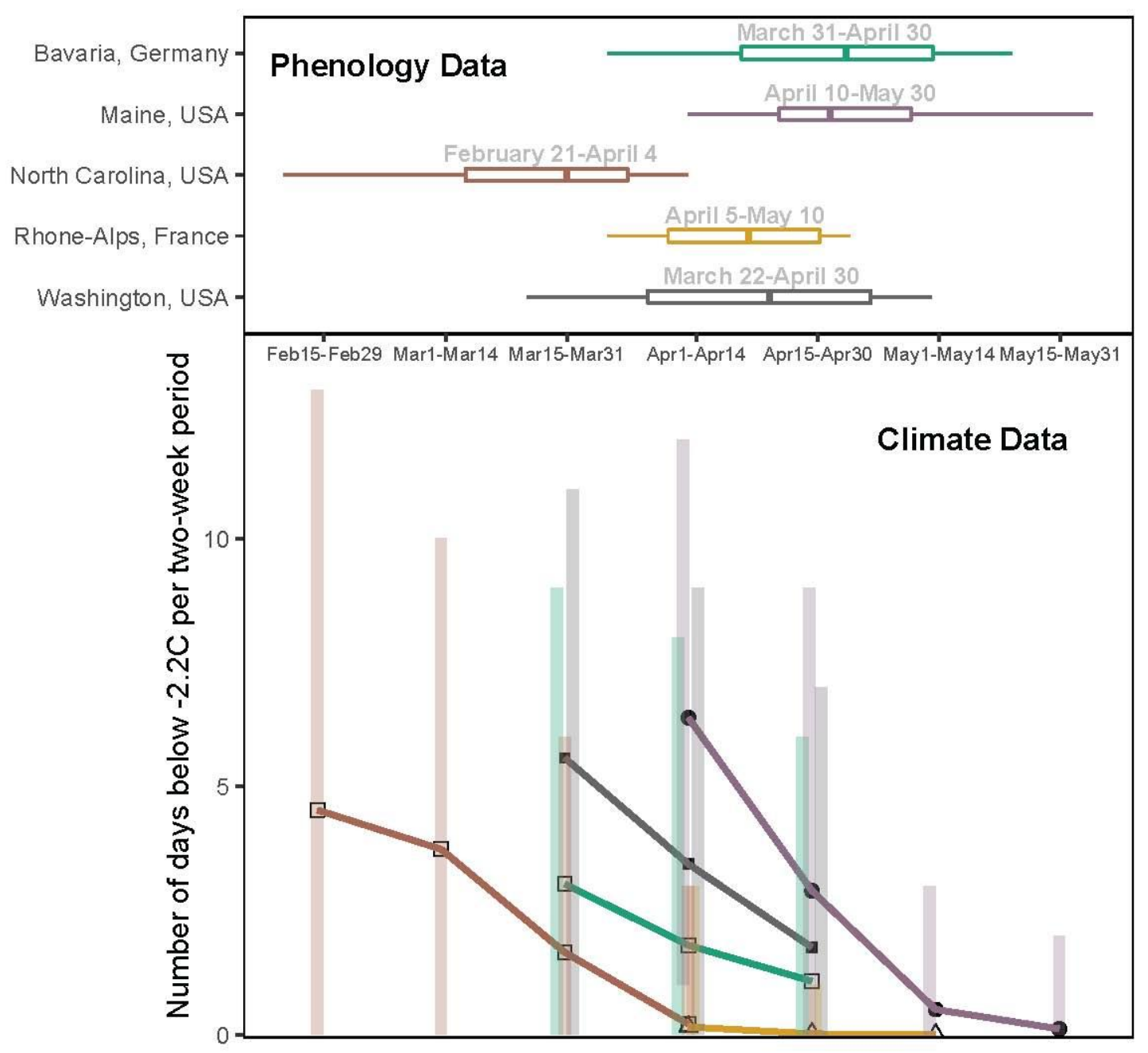

This article is protected by copyright. All rights reserved. 